wystapień na sesji były zasadniczo dwie kwestie. pierwsza z nich dotyczyła uregulowań prawnych związanych $\mathrm{z}$ ochroną dziedzictwa kulturowego $\mathrm{w}$ odniesieniu do archeologii. Tematyka drugiej części referatów obejmowała dokonania ostatnich lat w zakresie badań terenowych na obszarze Wielkopolski. Obrady zamknęło niezwykle interesujące wystapienie Jubilatki, podsumowujące badania nad początkami państwa piastowskiego. Materiały z tej sesji ukażą się drukiem dzięki wsparciu finansowemu generalnego konserwatora zabytków.

Drugą część dnia wypełniły uroczystości jubileuszowe. Rozpoczęła je laudacja wygłoszona przez niżej podpisaną, która przypomniała zebranym liczne, nie tylko czysto naukowe dokonania Pani Profesor na niwie archeologii, i w imieniu zespołu redakcyjnego wręczyła Jubilatce księgę pamiątkową pt. Kraje stowiańskie w wiekach średnich. Profanum $i$ sacrum. Na tę imponujących rozmiarów pracę złożyło się 68 artykułów autorów z Czech. Niemiec, Polski, Rosji, Rumunii, Słowenii i Ukrainy, nie tylko archeologów, ale też historyków i przyrodników. Pochwałę Jubilatki w serdecznych słowach wygłosiła prof. dr hab. Teresa Jakimowicz i prof. dr hab. Lech Leciejewicz; odczytano też nadesłane życzenia. Część oficjalną zakończyło wystąpienie Profesor Zofii Kurnatowskiej, z pełną ciepła i przewrotnego humoru refleksją nad przebytą drogą zawodową. Piękna pogoda i miejsce obchodów - wyspa na Jeziorze Lednickim - było znakomitą oprawą dla tego koleżeńskiego spotkania, zakończonego wieczorem wspólnymi śpiewami przy ognisku.

Hanna Kóčka-Krenz

\title{
ARCHIWUM PRYWATNE PROFESORA JÓZEFA KOSTRZEWSKIEGO
}

W czerwcu 2000 roku Instytut Prahistorii UAM w Poznaniu nabył drogą kupna, od spadkobierczyni Profesora, resztkę Jego archiwum prywatnego.

Zbiór ten składa się z rękopisów i druków (ponad 100 pozycji tworzących 13 grup tematycznych). Na szczególną uwagę zasługują:

- korespondencja Profesora z Żoną, z okresu okupacji hitlerowskiej,

- korespondencja oświęcimska Przemysława Kostrzewskiego - syna Profesora, z Matka,

- dokumenty dotyczace budowy domu w Strzeszynku,

- ekslibrisy,

- korespondencja abpa Antoniego Baraniaka, metropolity poznańskiego,

- dyplom Komandorii Orderu Św. Grzegorza Wielkiego,

- dyplomy doktoratów honoris causa,

- korespondencja z prof. Konradem Jażdżewskim i innymi archeologami łódzkimi.

W celu zapewnienia archiwaliom należytego bezpieczeństwa, a także w intencji scalenia materiałów po śp. Profesorze i tym samym lepszego wlączenia ich do obiegu naukowego, Instytut Prahistorii UAM przekazał swą własność - w formie długoterminowego depozytu do Archiwum PAN w Poznaniu (sygnatura P. III - 51). 